\section{Remote sensing as a tool to survey endemic diseases in Brazil}

\author{
O sensoriamento remoto como ferramenta \\ de vigilância em endemias brasileiras
}

\author{
1 Divisão de Processamento \\ de Imagens, Instituto \\ Nacional de Pesquisas \\ Espaciais, São José \\ dos Campos, Brazil. \\ 2 Escola Nacional de Saúde \\ Pública, Fundação Oswaldo \\ Cruz, Rio de Janeiro, Brazil. \\ 3 Divisão de Sensoriamneto \\ Remoto, Instituto Nacional \\ de Pesquisas Espaciais, \\ São José dos Campos, Brazil. \\ Correspondence \\ V. R. M. Correia \\ Divisão de Processamento de \\ Imagens, Instituto Nacional \\ de Pesquisas Espaciais. \\ Av. dos Astronautas 1758, \\ São José dos Campos, SP \\ 12201-027, Brasil. \\ virginia@dpi.inpe.br
}

\begin{abstract}
The objective of this study, based on a systematic literature review, is to present the characteristics and potentialities of remote sensing as a useful environmental surveillance tool for applied research in the control of endemics in Brazil. Onboard satellite sensors allow for monitoring the territory, furnishing spatial and temporal information on various scales and regions in the electromagnetic spectrum. Based on the literature review on the application of this technology to the study of endemics and the identification of the potential of new sensors with better spectral, spatial, and temporal resolutions, this study highlights perspectives for the use of remote sensing in the study of important endemics for Brazil.
\end{abstract}

Communicable Diseases; Epidemiologic Surveillance; Review Literature

\author{
Virginia Ragoni de Moraes Correia 1,2 \\ Marilia Sá Carvalho 2 \\ Paulo Chagastelles Sabroza 2 \\ Cíntia Honório Vasconcelos 3
}

\section{Introduction}

Recent environmental and ecological changes within a context of widespread increased social vulnerability, associated with the persistence of inadequate living conditions, have caused an impact on the distribution pattern of diseases. These environmental, economic, and social changes increase the epidemiological complexity, favoring the emergence of new diseases and the reemergence of old endemics, traditionally related to rural areas and currently occurring in new environments, as in the case of visceral leishmaniasis $1,2,3$. These questions have motivated health-related organizations, and particularly international agencies like the World Health Organization (WHO), to pursue the development of new surveillance techniques and models in which the environmental issue is fundamental 4 .

Remote sensing (RS) - a technology capable of acquiring information on the Earth's surface without any contact - allows systematic and regular monitoring of the Earth's environmental conditions, furnishing large amounts of spatial and temporal data and the possibility of extracting climatic and ecological information. Such information, together with appropriate field studies, can be used to identify and map the potential habitats of parasites and disease vectors; predict alterations in vector and parasite populations, monitoring quantitative and 
qualitative alterations in the respective habitats; and plan control programs, indicating areas of greater and lesser risk of the disease 5 .

The environmental factors most closely related to vector-borne endemics and amenable to observation from spatial platforms include: temperature, water, soil moisture, plant cover conditions, deforestation, urban characteristics, ocean color, and topography 6 .

Recognizing the potential of RS as well as its scarce utilization in Brazil, a review was conducted on the scientific knowledge acquired from applications of this technique to the study of endemic (and particularly vector-borne) diseases. The study attempts to identify possibilities for the use of this technology as a tool to support the study and control of the most frequent endemics in Brazil.

The article is developed along three main lines:

- Description of the main characteristics of sensors, seeking to provide the basis for discussing their use;

- The "state of the art" in the use of remote sensing applied to endemics;

- For each endemic, a description of its pattern, risk areas, information that the images can provide, and the satellites/sensors that can be utilized.

\section{Principal sensors and their characteristics and applications}

RS essentially measures the energy reflected or emitted in distinct and specific wavelengths in the electromagnetic spectrum, using sensors, usually on board satellites. When the objective of the monitoring is environmental, the visible, infrared, and microwave regions of the spectrum are used 7,8 .

RS systems can be classified as active or passive. In active systems, for example radar, Radio Detection and Ranging, the sensor emits a flow of radiation in the microwave spectral range which interacts with targets on the Earth's surface, and the reflected portion is captured by the sensor. The principal advantages of radar are that: it operates both daytime and nighttime; cloud cover does not impede its use; and it detects different textures and slopes. Passive systems record environmental energy - light and heat - reflected and emitted, captured by the sensor. The TM (Thematic Mapper) sensor from the LANDSAT (Land Satellites) series and the HRV (High Resolution Visible) sensor from SPOT (Satellite Pour l'Observation de la Terre) are examples of passive sensor systems 7 .
The different types of resolution that are characteristic of each sensor define the information content for each scene obtained.

Spectral resolution refers to the spectral range of each band in a given sensor and indicates the energy sample frequency. Since the targets display different responses in each of these spectral ranges, this information is used to identify such targets. For example, in an area of vegetation one observes a high reflectance value in the near-infrared region and a low value in the visible red band. Spatial resolution can be defined as the smallest possible area of terrain that can be individualized. Temporal resolution indicates the time interval between two satellite passes over the same point on Earth 9,10.

Table 1 shows the principal existing RS systems and their characteristics. The inclusion of the LANDSAT ETM+ sensor, out of operation since May 2003, is due to the large mass of data generated during its active period, from 1999 to 2003.

In the first contact with an RS image, the user utilizes such elements as tone, shape, size, pattern, texture, shadow, and association to interpret it. One can distinguish an urban area from a rural one, a more or less dense urban zone, crop areas from natural areas, and the rough texture of forest canopies from a smooth texture such as asphalt, crop fields, and pasture or grassy areas 7,11 .

As for the choice of images, one should use those with the most adequate spatial, spectral, and temporal resolutions for the study. In relation to spatial resolution, what is essential is to evaluate the size of the object one wishes to map. In the identification of small agricultural areas, trees, buildings, rooftop characteristics, and distances between residences, one can use a maximum 5-meter resolution. A 15-meter resolution is capable of detailing forest areas or identifying city blocks, while 20 to 30 -meter resolutions are ideal for identifying urban areas, roads, airports, and forest and agricultural areas, as well as characterizing land use. To detect floodable areas one can use spatial resolutions ranging from 10 to 100 meters, depending on the study area. A 1,000-meter resolution can be used to quantify vegetation and temperature 6 .

The images furnished by LANDSAT and SPOT satellites provide a scale of details that is impossible to obtain from the NOAA (National Oceanic and Atmospheric Administration) weather satellite. However the latter has high temporal resolution, allowing the acquisition of images from the same region with a 12-hour 
Spectral, spatial, and temporal characteristics of some satellite sensors.

\begin{tabular}{|c|c|c|c|c|c|c|c|}
\hline \multirow[t]{2}{*}{ Satellite } & \multirow[t]{2}{*}{ Sensor } & \multirow[t]{2}{*}{ Bands } & \multirow{2}{*}{$\begin{array}{l}\text { Spectral } \\
\text { range }(\mu \mathrm{m})\end{array}$} & \multirow{2}{*}{$\begin{array}{l}\text { Spectral } \\
\text { region }\end{array}$} & \multicolumn{2}{|c|}{ Resolution } & \multirow[t]{2}{*}{ Scene $(\mathrm{km})$} \\
\hline & & & & & Spatial (m) & Temporal (days) & \\
\hline \multicolumn{8}{|l|}{ NOAA } \\
\hline & AVHRR & 1 & $0.58-0.68$ & VIS & 1100 (nadir) & 0.5 & 833 \\
\hline & & 2 & $0.72-1.10$ & NIR & & & \\
\hline & & 3 & $3.55-3.93$ & MIR & & & \\
\hline & & 4 & $10.30-11.30$ & TIR & & & \\
\hline & & 5 & $11.50-12.50$ & TIR & & & \\
\hline \multicolumn{8}{|l|}{ Landsat } \\
\hline & TM, ETM+ & 1 & $0.45-0.52$ & Blue & 30 & 16 & 185 \\
\hline & & 2 & $0.52-0.60$ & Green & & & \\
\hline & & 3 & $0.63-0.69$ & Red & & & \\
\hline & & 4 & $0.76-0.90$ & NIR & & & \\
\hline & & 5 & $1.55-1.75$ & MIR & & & \\
\hline & & 6 & $10.40-12.50$ & TIR & 120 Landsat5 & & \\
\hline & & & & & 60 Landsat7 & & \\
\hline & & 7 & $2.08-2.35$ & MIR & 30 & & \\
\hline & ETM+ & 8 & $0.52-0.90$ & PAN & 15 & & \\
\hline \multicolumn{8}{|l|}{ Spot } \\
\hline & VEGETATION & 1 & $0.43-0.47$ & Blue & 1000 & 1 a 2 & 2250 \\
\hline & HRV, HRVIR & 1 & $0.50-0.59$ & Green & $20-20$ & 26,26 & 60 \\
\hline & HRV,HRVIR,VEG & 2 & $0.61-0.68$ & Red & 20. 20.1000 & $26,26,1-2$ & 60.60 .2250 \\
\hline & & 3 & $0.79-0.89$ & NIR & & & \\
\hline & HRV & PAN & $0.51-0.73$ & & 10 & 26 & 60 \\
\hline & HRVIR & PAN & $0.61-0.68$ & Red & & & \\
\hline & HRVIR,VEG & 4 & $1.58-1.75$ & MIR & 20.1000 & $26,1-2$ & 60.2250 \\
\hline \multicolumn{8}{|l|}{ Cbers } \\
\hline & $C C D$ & 1 & $0.45-0.52$ & Blue & 20 & 26 (Nadir) & 120 \\
\hline & & & & & & 3 days $(\sim 32 \circ)$ & \\
\hline & & 2 & $0.52-0.59$ & Green & & & \\
\hline & & 3 & $0.63-0.69$ & Red & & & \\
\hline & & 4 & $0.77-0.89$ & NIR & & & \\
\hline & & 5 & $0.51-0.73$ & PAN & & & \\
\hline & IR-MSS & 1 & $0.50-1.10$ & PAN & 80 e 160 (TIR) & 26 & 120 \\
\hline & & 2 & $1.55-1.75$ & MIR & & & \\
\hline & & 3 & $2.08-2.35$ & MIR & & & \\
\hline & & 4 & $10.04-12.05$ & TIR & & & \\
\hline & WFI & 1 & $0.63-0.69$ & Red & 260 & $3-5$ & 900 \\
\hline & & 2 & $0.77-0.89$ & NIR & & & \\
\hline \multirow[t]{5}{*}{ Ikonos } & & 1 & $0.45-0.52$ & Blue & 4 & 1-3 (off nadir) & 11(Nadir) \\
\hline & & 2 & $0.52-0.61$ & Green & & & \\
\hline & & 3 & $0.64-0.72$ & Red & & & \\
\hline & & 4 & $0.77-0.88$ & NIR & & & \\
\hline & & 5 & $0.45-0.90$ & PAN & 1 & & \\
\hline
\end{tabular}

MIR = Middle Infrared; NIR = Near Infrared; PAN = panchromatic $; \mathrm{TIR}=$ Thermal Infrared; VNIR: Visible Near Infrared. Lillesand \& Kiefer 7 . 
frequency, while LANDSAT and SPOT have temporal resolutions of 16 and 26 days, respectively. When the study is done on a regional or continental scale, one normally uses images that cover larger areas. In this case, one can use NOAA or TERRA satellite images. The same area would require a larger number of LANDSAT images, involving an additional cost.

IKONOS and QUICKBIRD images, whose spatial resolution is better, can be interesting for the study of densely populated urban areas. In tropical areas with heavy cloud cover, radar images can be useful. In addition, active microwave sensors are particularly valuable for monitoring flooded areas.

In addition to the spatial and temporal resolution, one should be alert to the spectral range that best identifies the target. Flooded forests can be detected using the SAR-L band from JERS-1 radar 12; for urban characteristics one can use the panchromatic band of SPOT or IKONOS 13. Ecotones can be best identified using bands in the spectrum between 0.4 and $1.3 \mu \mathrm{m}$, which includes visible and near-infrared, utilizing the LANDSAT, SPOT, or IKONOS satellite, depending on the desired detail 6 .

Factors related to endemics, such as the effects of climatic variations on vegetation, urban growth, and deforestation, require temporal follow-up. A combination of sensors from different satellites, like a fusion of radar and optical images, can be used in complementary fashion 14 .

Imaging processing techniques based on spectral responses can generate new information 8,9 . For example, using mixture modeling, one can create bands for the proportion of water, soil, and vegetation 15,16. Operation of NDVI, Normalized Difference Vegetation Index, has also created a biomass information band that can indicate possible habitats of disease vectors and reservoirs. The operation, which transforms the spectral components represented in the RGB (Red, Green, Blue) color space into a system that furnishes information on intensity, hue, and saturation, can be useful for image fusion, thus allowing to use SPOT-PAN spatial resolution while keeping LANDSAT-TM spectral resolution 17 .

TERRA, the Latin term for "Land", a land observation satellite launched by NASA in 1999, has great potential for studying endemics. This satellite has various sensors, including MODIS (Moderate Resolution Imaging Spectroradiometer) and ASTER (Advanced Spaceborne Thermal Emission and Reflection Radiometer). The former has 36 spectral bands with 250, 500, and 1,000-meter resolutions and a 2-day temporal resolution. The latter has three 15-meter resolution bands in the $0.5-0.9 \mu \mathrm{m}$ region, six 30 meter resolution bands in the $1.6-2.5 \mu \mathrm{m}$ region, and five 90 -meter bands in the $8-12 \mu \mathrm{m}$ region, with a 16-day temporal resolution These sensors are capable of monitoring land environmental factors in various resolutions 7,10 .

In addition to the sensors already in operation, space agencies are expected to launch more than 80 missions by the year 2010 , with instruments capable of measuring environmental change parameters with improved spectral, spatial, and temporal resolutions 6 . The literature related to RS application in the study of vector-borne diseases has grown, and new research perspectives are opening up with the emergence of sensors with improved resolutions.

\section{Systematic review}

The systematic literature review covered the period from 1996 to 2002, searching the following sources: MEDLINE (Medical Literature, Analysis, and Retrieval System Online), using "remote sensing" as the keyword; articles referred to in these publications when not indexed in MEDLINE; the Internet, especially the CDC website (Centers for Disease Control and Prevention) 18 and CHAART (Center for Health Applications of Aerospace Related Technologies - http://www.geo.arc.nasa.gov/sge/health); SciELO (Scientific Electronic Library Onlinehttp://www.scielo.br); and the thesis/dissertation database of CAPES (Coordenação de Aperfeiçoamento de Pessoal de Nivel Superior http: / / www.ged.capes.gov.br/agdw/silverstream/pages/frPesquisaTeses.html).

Table 2 provides a summary of the result of the systematic review, the reference for which was the pioneering work of Beck et al. 9. Several contributions 19,20,21,22,23,24,25,26,27,28 were not included, since they were already reviews themselves.

Among the various sensors used, including in the Brazilian studies, there was a predominance of AVHRR (NOAA) and TM (LANDSAT), possibly because they are the oldest and with a broad historical series. There are still no studies applied to health using the high-resolution images from the QUICKBIRD or IKONOS satellites. As for radar images, no references were found, although they are mentioned in some articles as a potential resource for detecting floodable areas, possible habitats for mosquito larvae 25,28.

The review showed that most applications refer to the continental scale, with few on ur- 
Literature review.

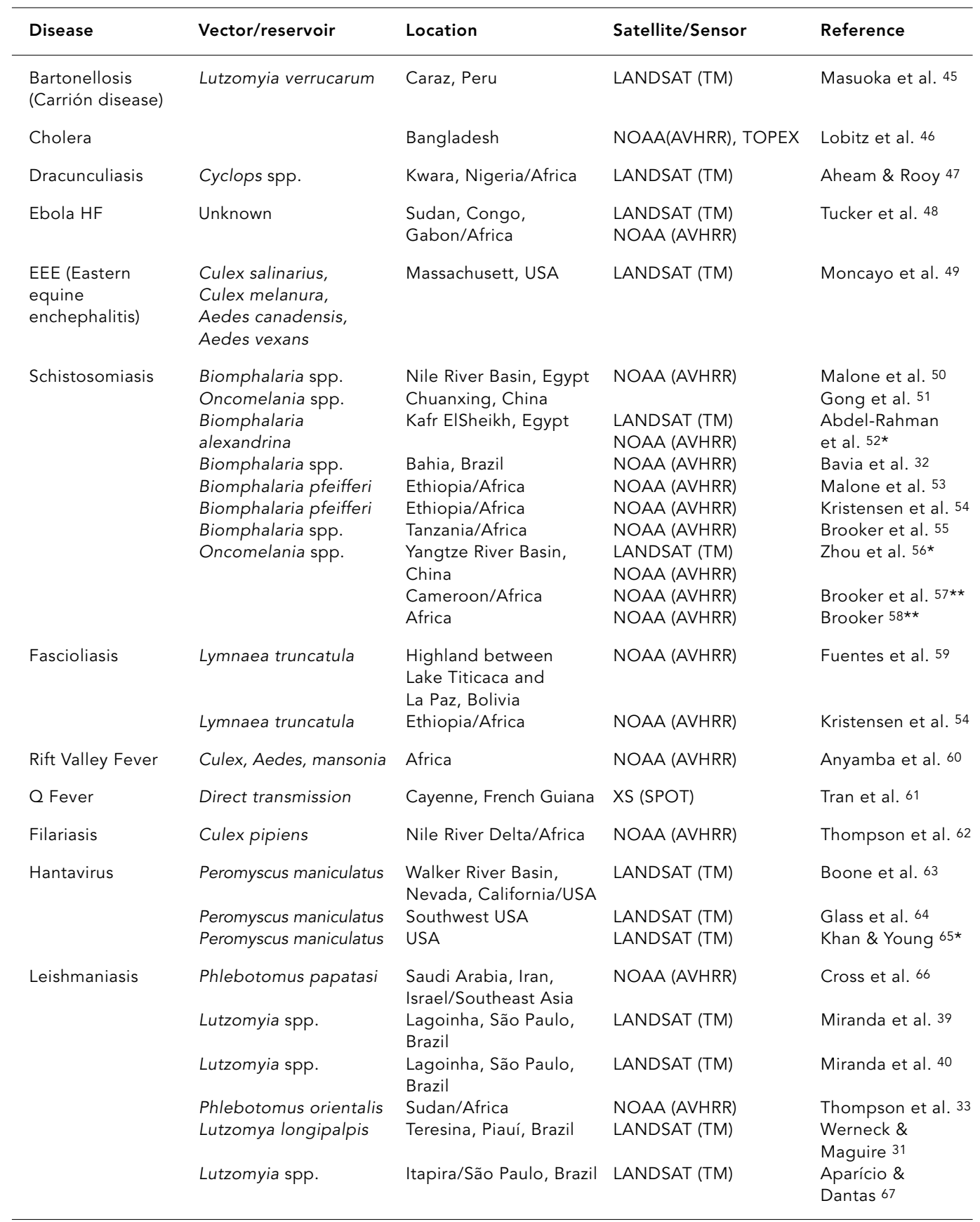

(continued) 
Table 2 (continued)

\begin{tabular}{|c|c|c|c|c|}
\hline Disease & Vector/reservoir & Location & Satellite/Sensor & Reference \\
\hline \multirow[t]{5}{*}{ Lyme disease } & Ixodes scapularis & $\begin{array}{l}\text { Chappaqua and } \\
\text { Armonk, Westchester } \\
\text { County, NY, USA }\end{array}$ & LANDSAT (TM) & Dister et al. 68 \\
\hline & Ixodes scapularis & Wisconsin, USA & NOAA (AVHRR) & $\begin{array}{l}\text { Kitron \& } \\
\text { Kazmierczak } 69\end{array}$ \\
\hline & Ixodes scapularis & $\begin{array}{l}\text { Pennsylvania, New York, } \\
\text { Wisconsin, Virginia, } \\
\text { Northern California, } \\
\text { Midwest USA }\end{array}$ & NOAA (AVHRR) & Estrada-Peña 70 \\
\hline & Ixodes scapularis & $\begin{array}{l}\text { Wisconsin, Illinois, } \\
\text { Michigan, USA }\end{array}$ & LANDSAT (TM) & Guerra et al. 71 \\
\hline & Ixodes scapularis & $\begin{array}{l}\text { Northeast to } \\
\text { Southeast USA }\end{array}$ & NOAA (AVHRR) & Estrada-Peña 72 \\
\hline \multirow[t]{18}{*}{ Malaria } & An. albimanus & Central Belize & SPOT (XS) & Roberts et al. 73 \\
\hline & An. albimanus & Chiapas, Mexico & Aerial photos & Rodriguez et al. 74 \\
\hline & An.gambiae & Gambia/Africa & $\begin{array}{l}\text { NOAA (AVHRR), } \\
\text { METEOSAT }\end{array}$ & Thompson et al. $75^{*}$ \\
\hline & Anopheles albimanus & $\begin{array}{l}\text { Tapachula, Chiapas, } \\
\text { Mexico }\end{array}$ & LANDSAT (TM) & Beck et al. 76 \\
\hline & Anopheles spp. & Gambia & $\begin{array}{l}\text { NOAA (AVHRR), } \\
\text { METEOSAT }\end{array}$ & Thompson et al. 77 \\
\hline & Anopheles spp. & USA, Mexico, Africa & $\begin{array}{l}\text { LANDSAT (MSS), } \\
\text { LANDSAT (TM) } \\
\text { NOAA (AVHRR), } \\
\text { METEOSAT }\end{array}$ & Hay et al. $78^{\star}$ \\
\hline & Anopheles spp. & $\begin{array}{l}\text { Kilifi and Siaya, } \\
\text { Kenya/Africa }\end{array}$ & $\begin{array}{l}\text { NOAA (AVHRR), } \\
\text { METEOSAT }\end{array}$ & Hay et al. 79 \\
\hline & $\begin{array}{l}\text { An. punctimaluca } \\
\text { An. vestitipennis }\end{array}$ & Belize & SPOT (XS) & $\begin{array}{l}\text { Rejmankova } \\
\text { et al. } 80\end{array}$ \\
\hline & Anopheles spp. & Africa & $\begin{array}{l}\text { NOAA (AVHRR), } \\
\text { METEOSAT }\end{array}$ & Connor et al. 35* \\
\hline & An. gambiae & Gambia/Africa & NOAA (AVHRR) & Thompson et al. 81 \\
\hline & An. subpictus & $\begin{array}{l}\text { Lombok Island, } \\
\text { Indonesia }\end{array}$ & JERS (optic) & Anno et al. 82 \\
\hline & An. funestus & Ihosy and Ambalavao & LANDSAT (TM) & Jeanne 83 \\
\hline & & $\begin{array}{l}\text { Districts, Madagascar/ } \\
\text { Africa }\end{array}$ & SPOT (PAN) & \\
\hline & Anopheles spp. & Africa & $\begin{array}{l}\text { LANDSATMSS) } \\
\text { LANDSAT (TM) SPOT, } \\
\text { NOAA (AVHRR) }\end{array}$ & Hay et al. 84 \\
\hline & An. gambiae & Gambia/Africa & SPOT (XS) & $\begin{array}{l}\text { Thomas \& } \\
\text { Lindsay } 85\end{array}$ \\
\hline & Anopheles spp. & Kyunggi Province/Korea & LANDSAT (TM) & Claborn et al. 86 \\
\hline & Anopheles spp. & $\begin{array}{l}\text { Tanzania, Uganda, } \\
\text { and Kenya/Africa }\end{array}$ & NOAA (AVHRR) & Omumbo et al. \\
\hline & Anopheles spp. & Africa & & Rogers et al. 88* \\
\hline $\begin{array}{l}\text { RRV (Ross River } \\
\text { Virus) }\end{array}$ & Culex annulirostris & Brisbane, Australia & Colored aerial photos & Dale \& Morris 89 \\
\hline \multirow[t]{7}{*}{ Trypanosomiasis } & Glossina spp. & Kenya/Africa & LANDSAT (TM) & Kitron et al. 69 \\
\hline & Glossina spp. & $\begin{array}{l}\text { Côte d'Ivoire and } \\
\text { Burkina Faso/Africa }\end{array}$ & NOAA (AVHRR) & Rogers et al. 90 \\
\hline & Glossina spp. & Southern Africa & NOAA (AVHRR) & Robinson et al. 91 \\
\hline & Glossina spp. & Southern Africa & NOAA (AVHRR) & Robinson et al. 92 \\
\hline & Glossina tachinoides & Togo/Africa & $\begin{array}{l}\text { NOAA (AVHRR) } \\
\text { METEOSAT }\end{array}$ & Hendrickx et al. 93 \\
\hline & Glossina spp. & Africa & NOAA (AVHRR) & Rogers 94 \\
\hline & Glossina spp. & Bukina Faso/Africa & LANDSAT (TM) SPOT & $\begin{array}{l}\text { De La Rocque } \\
\text { et al. } 95\end{array}$ \\
\hline
\end{tabular}

TOPEX: http://topex-www.jpl.nasa.gov/science/science.htm METEOSAT: http://satelite.cptec.inpe.br/

* Review articles.

** Journal articles related to RS that do not specify the vector. 
ban areas. Most information obtained by satellite is correlated to vegetation, utilizing NDVI, an index obtained from operations with spectral bands. For example, in the case of NOAA, utilizing bands 1 and 2 from the AVHRR sensor, one can highlight the vegetation through the following operations: band2/band1 or (band2band 1 )/band $2+$ band 1 . These operations can also be used based on LANDSAT, with the same objective, using bands TM4 and TM3. The enhancement of vegetation using these operations is due to the high spectral response of vegetation as compared to the soil in band 4 of the TM sensor and band 2 of AVHRR 29,30.

The methodologies correlating this measurement with target epidemiological indicators varied considerably in the studies. Werneck \& Maguire 31 use NDVI as the independent variable in a mixture modeling in order to explain the incidence rate for visceral leishmaniasis in census tracts in the city of Teresina, Piauí. In the State of Bahia, Bávia et al. 32 use a multiple regression model in which NDVI is one of the explanatory variables. Thompson et al. 33 utilize NDVI as the dependent variable in a logistic regression to study the probability of occurrence of the vector Plebotomus orientalis in various locations in Sudan, Africa. Kitron \& Kazmierczak 34 use the spatial autocorrelation measurement Moran's I to identify the degree of spatial grouping of cases of Lyme disease, ticks, and vegetation (NDVI) in Wisconsin, USA.

Considering the number of references (Table 2), malaria has been the most extensively studied endemic in this environmental context, utilizing a variety of high and low-resolution sensors. Risk of malaria infection, its spread, and seasonality are determined by the combination of human exposure, high vector density, the time the parasite takes to develop in the mosquito, vector survival rate, parameters influenced by meteorological variables such as temperature, precipitation, and relative humidity, deforestation, and bodies of water, which can be mapped by RS directly or using measures such as the vegetation index, surface temperature, and cloud temperature 35 . Despite this relevance of this endemic in Brazil, only three studies were located on RS and malaria $36,37,38$.

Of the six articles found on leishmaniasis (Table 2), five apply to Brazilian regions. Three of these article refer to tegumentary leishmaniasis (TL) in Southeast Brazil 39,40,41 and the others to visceral leishmaniasis (VL) in the Northeast. Of the latter, one deals with climatic and demographic determinants of VL in the town of Canindé, Ceará 42; another is an ecological study of VL in the city of Teresina, Piauí 31 . The
CAPES thesis/dissertation database included three dissertations utilizing LANDSAT images to study tegumentary leishmaniasis $41,43,44$.

Schistosomiasis is an important endemic in various tropical and subtropical countries and has been extensively studied, with a predominant utilization of the AVHRR sensor (Table 2). The number of references to schistosomiasis is due mainly to a special issue of Acta Tropica, dedicated to the study of the disease with a focus on the use of RS and GIS techniques. One of the articles presents an application in the State of Bahia 32 in which the authors used products derived from the AVHRR sensor, vegetation index, and diurnal temperature difference, to verify the relationship between the environment and density of schistosomiasis distribution. The authors go on to utilize these factors in a forecasting model to calculate the environmental risk of the disease in the municipalities in the State of Bahia. The authors used the SPRING-GIS software to develop and analyze maps for NDVI and dT (diurnal temperature difference).

\section{Environment and endemics - challenges}

Table 3, based on the description of possible ecological, socio-environmental, and soil-use characteristics related to the occurrence of endemics in Brazil, attempts to systematize the potential use of RS, discussing the variety of favorable environments. This table should be read as a challenge for researchers, raising hypotheses that orient this type of work, without the aim of exhausting the subject. In some cases the table categorizes the epidemiological pattern for the occurrence of the endemic in sub-groups in order to facilitate the characterization of environmental aspects detectable by RS. In all the references to specific sensors, the most accessible and lowest-cost sensor was prioritized, although it is possible to use finer resolutions. Each object of study has its specificities, and due to the diversity of factors involved, it is often necessary to use various sensors with different resolutions. In addition, complementary data from other sources included in a Geographic Information System may be necessary. Therefore, the objective is not to limit the applications to specific sensors, but to convey the idea of plurality, possibilities, and also limitations. The principal aspects of some of these endemics are listed below.

In mapping Chagas disease transmission areas, the land occupation pattern can be identified by using images with a resolution of up 
Principal transmissible diseases and some forms of occurrence in Brazil with associated environmental factors that can be tracked by remote sensing

\begin{tabular}{|c|c|c|c|c|c|}
\hline Disease (Parasite) & $\begin{array}{l}\text { Vectors and } \\
\text { Reservoirs }\end{array}$ & Region of Brazil & Pattern & Risk areas & $\begin{array}{l}\text { What to map in the risk areas. } \\
\text { RS factors. }\end{array}$ \\
\hline $\begin{array}{l}\text { Chagas disease } \\
\text { (Trypanosoma cruzi) }\end{array}$ & $\begin{array}{l}\text { Insects (triatomines } \\
\text { or kissing bugs), } \\
\text { of genera Triatoma } \\
\text { and Panstrongilus } \\
\text { Wild marsupials } \\
\text { and rodents }\end{array}$ & $\begin{array}{l}\text { North and } \\
\text { Northeast }\end{array}$ & $\begin{array}{l}\text { Domiciliary } \\
\text { Peridomiciliary }\end{array}$ & $\begin{array}{l}\text { Small towns and rural } \\
\text { settlements with } \\
\text { precarious housing. } \\
\text { Traditional farming areas } \\
\text { in the semi-arid region }\end{array}$ & $\begin{array}{l}\text { Clusters of precarious housing at } \\
\text { a short distance from the natural } \\
\text { vegetation. } \\
\text { Dry regions with, rocky } \\
\text { outcroppings and domestic } \\
\text { animal shelters in a semi- } \\
\text { extensive regimen }\end{array}$ \\
\hline $\begin{array}{l}\text { Schistosomiasis } \\
\text { (Schistosoma } \\
\text { mansoni) }\end{array}$ & $\begin{array}{l}\text { Snails of the } \\
\text { Biomphalaria gender }\end{array}$ & $\begin{array}{l}\text { Northeast and } \\
\text { Southeast }\end{array}$ & Peri-urban & $\begin{array}{l}\text { Small or medium-sized } \\
\text { towns located in } \\
\text { agricultural areas, } \\
\text { permanent bodies of } \\
\text { water used in domestic } \\
\text { and recreational activities } \\
\text { and contaminated with } \\
\text { human feces }\end{array}$ & $\begin{array}{l}\text { Bodies of water on urban } \\
\text { peripheries and agricultural } \\
\text { areas without sanitation. } \\
\text { Urban expansion in agricultural } \\
\text { regions. } \\
\text { Permanent bodies of water with } \\
\text { natural vegetation }\end{array}$ \\
\hline $\begin{array}{l}\text { Yellow fever } \\
\text { (arbovirus of the } \\
\text { Flavivirus gender) }\end{array}$ & $\begin{array}{l}\text { Dípterans of the } \\
\text { Haemagogus gender. } \\
\text { Various species of } \\
\text { monkeys, principally } \\
\text { of the Alouata gender }\end{array}$ & $\begin{array}{l}\text { Amazon Region } \\
\text { and States of } \\
\text { Goiás, Minas } \\
\text { Gerais, São Paulo, } \\
\text { Paraná, Santa } \\
\text { Catarina, Rio } \\
\text { Grande do Sul }\end{array}$ & Sylvatic & $\begin{array}{l}\text { Equatorial and tropical } \\
\text { forests larges enough to } \\
\text { maintain populations of } \\
\text { monkeys; riparian forests, } \\
\text { ecological integration } \\
\text { corridors }\end{array}$ & $\begin{array}{l}\text { Areas of deforestation and paths/ } \\
\text { roads penetrating the forests. } \\
\text { Markers of anthropic pressure in } \\
\text { areas with forest cover. } \\
\text { Riparian forests in settings with } \\
\text { ecological tension. } \\
\text { Housing settlements near forests, } \\
\text { with large spots of vegetation }\end{array}$ \\
\hline $\begin{array}{l}\text { Hantavirus (various } \\
\text { viruses from the } \\
\text { Buyanviridae family) }\end{array}$ & $\begin{array}{l}\text { Wild rodents of the } \\
\text { genera Akodon, } \\
\text { Bolomys and } \\
\text { Oligoryzomys }\end{array}$ & $\begin{array}{l}\text { Southeast, South, } \\
\text { and Central-West }\end{array}$ & Rural & $\begin{array}{l}\text { Rural areas with crops that } \\
\text { produce large amounts } \\
\text { of seeds, allowing the } \\
\text { expansion of a population } \\
\text { of wild rats }\end{array}$ & $\begin{array}{l}\text { Agricultural areas with extensive } \\
\text { grain crops, like soybeans, wheat, } \\
\text { and corn. } \\
\text { Proximity between households } \\
\text { and crop areas. } \\
\text { Stages of seed formation in the } \\
\text { different crop cycles }\end{array}$ \\
\hline $\begin{array}{l}\text { Leptospirosis } \\
\text { (bacteria of the } \\
\text { Leptospira gender) }\end{array}$ & Rodents & $\begin{array}{l}\text { Metropolises in } \\
\text { the Northeast } \\
\text { and Southeast }\end{array}$ & Urban & $\begin{array}{l}\text { Urban areas with precarious } \\
\text { sanitation, high density of } \\
\text { human inhabitants and } \\
\text { rodents, subject to } \\
\text { occasional floods. } \\
\text { Grain crops in flooded areas }\end{array}$ & $\begin{array}{l}\text { Precarious urban areas located in } \\
\text { regions with little slope. } \\
\text { Proximity of the urban areas to } \\
\text { creeks and garbage dumps. } \\
\text { Flooded areas in urban centers. } \\
\text { Flooded terrain in rice } \\
\text { plantations }\end{array}$ \\
\hline
\end{tabular}

to 30 meters, allowing the identification of neighborhoods and estimated distances to breeding sites. In the case of schistosomiasis, mapping bodies of water in the middle of natural vegetation is of fundamental importance. Various sensors, including microwave sensors, can contribute to the study and choice of the sensor and should prioritize the size of these bodies of water. Imaging in this case helps detect risk areas and can support control measures by estimating the size of surfaces for use of molluscicide.

Sylvatic yellow fever is of great importance due to its high case fatality rate. One of the fun- damental questions in this case is the risk of reaching populations in areas lacking vaccine coverage, which depends on the occurrence of monkey epizootics in these regions. Images can help detect forest corridors through which populations of infected monkeys can migrate. In this case, the images furnished by LANDSAT, SPOT, CBERS-CCD, and TERRA-ASTER sensors can be useful by identifying fragments of forests.

Leptospirosis occurs in Brazil with two distinct profiles: urban, related to areas with a high density of rats, with outbreaks following floods, and rural. The most susceptible locations are thus areas that concentrate water and mud. Al- 
though civil defense in cities has usually defined the potentially floodable areas, the definition is relatively gross. Images can help identify flooded areas and, together with slope information, more precisely map the risk areas. In this case the disease's seasonality also calls for periodic imaging. Radar images, although useful in slope identification and when there is cloud coverage, would contribute little to more detailed mapping of urban areas due to interference by the signal reflection on various other surfaces (European Space Agency - http:// www.envisat.esa.int/dataproducts/asar). In this type of application, the images should display high spatial and temporal resolution and be available soon after the rain, in order to allow mapping of the wet flooded areas. Ideally, these images would be available as soon as they are acquired, like those used for weather forecasting, but this is not the case at present.

Visceral leishmaniasis was formerly transmitted mainly in forest areas or concentrated in small rural settlements, with the fox as the main reservoir. More recently VL has occurred in medium-sized Brazilian cities with low plant cover and the dog as the main reservoir, with the disease related to the organization and expansion of urban space 31 . LANDSAT, SPOT, and IKONOS sensors can be used to detect areas of vegetation, the limits between forests and urban areas, areas of vegetation within cities, the proximity between forests and residences, and the housing quality and pattern.

Two patterns of malaria occur in Brazil, and one can use images to detect deforested areas, bodies of water, expansion of the urban grid, areas of vegetation, and other characteristics that can point to possible resting and breeding sites for the mosquito vector. Radar images show promise for studying this endemic, complementing information in areas where the responses to optic sensors have limitations.

Tegumentary leishmaniasis, due to the complexity of its cycle, was not included in Table 3. This disease has occurred endemically and epidemically with different transmission patterns, which can be related to: human penetration of sylvatic foci, whether by the expansion of agricultural frontiers or other activities like ecotourism; the rural mosaic, with the interspersing of agricultural areas with secondary forests and scrub growth; areas of urban expansion with housing projects on the limits between the city and the forest or environmental preservation areas, with the adaptation of vectors, reservoirs, and parasites to modified environments. Various factors related to the scenarios described above can be detected by images: deforested areas, by the contrast between the vegetation and the soil; new rural settlements, using the irregular texture in the deforested areas; and the opening of roads, using the information on the contrast between the vegetation and the soil and the elongated and narrow shape. In the rural pattern, the risk areas are those involving agricultural use, which are normally identified with images due to their regular shape and their interspersing with secondary forests and scrub growth, giving the appearance of a mosaic. The areas occupied by the population can be identified by the irregular pattern in the geometric shapes of the dwellings. The paths used by people to circulate, when not identified, can be inferred by the distance between rural clusters in the agricultural areas. The urban pattern is observed when, due to population growth, new housing projects are built on the limits between the city and the forest, as in Manaus, or when transmission foci are located on the limits between urbanized and environmental preservation areas, as in Rio de Janeiro. Among many factors, images acquired on different dates can identify areas of urban growth, variation in plant cover, land use, and environmental preservation areas in urban spaces. Images provided by the TM sensor in the LANDSAT satellite can provide a good option for identifying these patterns, and SPOT can be used when finer resolution is necessary.

Other endemics can also be explored, like onchocerciasis, filariasis, and dengue. The latter, in which intradomiciliary transmission is decisive in maintaining what until recently was a scarcely "visible" endemic for remote sensors, has some environmental aspects which contribute substantially to reproduction of the vector (Aedes aegypti). Open-air storage of used tires, large open water tanks, and abandoned swimming pools account for the extensive proliferation of these insects after rain and can be located using high-resolution sensors.

\section{Final remarks}

An environmental context predisposing to the occurrence of various endemics can be captured by the spatial, temporal, and spectral resolutions of RS satellite onboard sensors. Remote sensing, combined with other technologies like GPS (Global Positioning System), capable of spatially locating the event, and GIS (Geographic Information System), add qualified information for the identification of vulnerable ecosystems, at a relatively low cost, thus pro- 
viding an important ancillary (and previously little-explored) tool for studying certain endemics and supporting surveillance and control activities.

The use of statistical and computational methods and techniques, in addition to digital processing of satellite images, expands the prospects for research on the spatial distribution of diseases and the possibility of creating risk maps based on multivariate and hierarchical models. In addition, the role of this technology remains to be explored for supporting the implementation of endemic surveillance activities. Substantial improvements can be made in estimates of vector control inputs, based on calculations of the extension of settled areas; optimization of routes for visits by health agents; and identification of potential new foci, whether by expansion of urban areas or opening of trails in the forest.

Despite the opportunities this technology offers for studying endemics, its utilization is still limited by the cost and lack of knowledge of its potential. However, some images, like those from the NOAA and TERRA satellites, can be acquired free of cost (http://daac.gsfc.nasa. gov). The CBERS 2 images are also available, free of charge, at http://www.dpi.inpe.br/catalogo, having their use restricted by the license one can find at the same address. The LANDSAT, SPOT, IKONOS images and others can be ordered for any region of Brazil via internet (INPE - http:/ / www.dgi.inpe.br, GISPLAN - http: //www.gisplan.com.br, ENGESAT - http://www. engesat.com.br). Some of these images, for example LANDSAT, have quite affordable prices. Although commercial software programs for data processing currently available on the market are still expensive, there is a viable publicdomain alternative, SPRING-GIS, which integrates image processing functions and statistical modeling algorithms for environmental data. The greatest limitation in our opinion is technical training in the health field, allowing for the gradual incorporation of this technology.

\section{Resumo}

O objetivo deste trabalho é, a partir de revisão bibliográfica sistemática, apresentar as características e potencialidades do remote sensing como ferramenta de vigilância ambiental útil para pesquisas aplicadas ao estudo e controle de endemias brasileiras. Os sensores a bordo dos satélites permitem monitorar o território fornecendo informação espacial e temporal em várias escalas e regiões do espectro eletromagnético. Baseado na revisão bibliográfica sobre a aplicação dessa tecnologia no estudo de endemias, e na identificação do potencial dos novos sensores, com melhores resoluções espectrais, espaciais e temporais, este trabalho aponta perspectivas para o uso do Sensoriamento Remoto no estudo de endemias importantes para o Brasil.

Doenças Transmissíveis; Vigilância Epidemiológica; Literatura de Revisão

\section{Contributors}

All the authors contributed to the concept, methodological development, discussion, and elaboration of the article. 
1. Boulos M. Doenças emergentes e reemergentes no Brasil. Ciência Hoje 2001; 39:58-60.

2. Possas CA. Social ecosystem health: confronting the complexity and emergence of infectious diseases. Cad Saúde Pública 2001; 17:31-41.

3. Schatzmayr HG. Viroses emergentes e reemergentes. Cad Saúde Pública 2001; 17 Suppl: 209-13.

4. Pan American Health Organization. Second meeting of the task force on surveillance for emerging and reemerging infectious diseases. http://www. paho.org/english/hcp/hct/eer/eid-eer.htm (accessed on 10/Jun/2003).

5. Hugh-Jones M. Applications of remote sensing to the identification of the habitats of parasites and disease vectors. Parasitol Today 1989; 5:244-51.

6. Beck LR, Lobitz BM, Wood BL. Remote sensing and human health: new sensors and new opportunities. Emerg Infect Dis 2000; 6:217-27.

7. Lillesand TM, Kiefer RW. Remote sensing and image interpretation. New York. John Wiley \& Sons; 1999.

8. Richards JA. Remote sensing digital image analysis: an introduction. 2nd Ed. Berlin: Springer-Verlag; 1993.

9. Jensen JR. Introductory digital image processing: a remote sensing perspective. 2nd Ed. New Jersey: Prentice-Hall; 1996.

10. Moreira MA. Fundamentos do sensoriamento remoto e metodologias de aplicação. 1ạ Ed. São José dos Campos: Editora Com Deus, Comunicação Católica; 2001.

11. Moreira MA. Complemento do Livro-Sensores INPE (Instituto Nacional de Pesquisas Espaciais). http://www.Ltid.Inpe.Br/Dsr/Mauricio/Livro.Ht $\mathrm{ml}$ (accessed on 19/Jul/2003).

12. Costa MPF, Novo EML, Mitsuo IIF, Montovani JE, Ballester MV, Ahern FJ. Classification of floodplain habitats (Lago Grande, Brazilian Amazon) with Radarsat and JERS-1 Data. In: Proceedings of Geomatics in the Era of Radarsat (GER'97); 1997 May 25-30; Ottawa, Canada. Ottawa: Canadian Aeronautics and Space Institute; 1997.

13. Kuo CY, Chou TY, Lee RY. Identification of urban characteristics using IKONOS high resolution satellite image. In: Proceedings of 22nd Asian Conference on Remote Sensing, Singapore. 5-9 November 2001. http://www.crisp.nus.edu.sg/ (accessed on 09/Oct/2001).

14. Qinghua Y, Zhizhong L, Hongbin F, Maocheng Y, Zhigang S, Shuenxi L, et al. Application of radar image in land-use dynamic monitoring in Beijing. In: Proceedings of 22nd Asian Conference on Remote Sensing. Singapore. 5-9 November 2001. http://www.crisp.nus.edu.sg/ (accessed on 09/ Oct/2001).

15. Shimabukuro Y, Batista G, Mello E, Moreira J, Duarte V. Using shade fraction image segmentation to evaluate deforestation in LANDSAT thematic mapper images of the Amazon region. Int J Remote Sens 1998; 19:535-41.

16. Aguiar APD, Shimabukuro YE, Mascarenhas ND. Use of synthetic bands derived from mixing models in the multispectral classification of remote sensing images. Int J Remote Sens 1999; 20:647-57.
17. Correia VRM, Felgueiras CA, Dutra LV. Integração de dados de modelos numéricos de terreno e imagens de satélite utilizando transformação IHS. In: Anais do VI Simpósio Brasileiro de Sensoreamento Remoto. 1990 Jun 24-29; Manaus, Brasil. São José dos Campos: Instituto Espacial de Pesquisas Espaciais; 1990. vol 3.

18. Centers for Disease Control and Prevention. Emerging infectious diseases. http://www.cdc. gov/Ncidod (accessed on 10/Jun/2003).

19. Hay SI, Tucker CJ, Rogers DJ, Packer MJ. Remotely sensed surrogates of meteorological data for the study of the distribution and abundance of arthropod vectors of disease. Ann Trop Med Parasitol 1996; 90:1-19.

20. Hay SJ, Packer MJ, Rogers DJ. The impact of Remote Sensing on the study and control of invertebrate intermediate hosts and vectors for disease. International. Journal of Remote Sensing 1997; 18:2899-930.

21. Hay SI, Lennon JJ. Deriving meteorological variables across Africa for the study and control of vector-borne disease: a comparison of remote sensing and spatial interpolation of climate. Trop Med Int Health 1999; 4:58-71.

22. Hay SI, Randolph SE, Rogers DJ. Remote sensing and geographical information systems in epidemiology. New York: Academic Press; 2000.

23. Dale PER, Ritchie AS, Territo BM, Morris CD, Muhar A, Kay BH. An overview of Remote Sensing and GIS for surveillance of mosquito vector habitats and risk assessment. J Vector Ecol 1998; 23: 54-61.

24. Kitron U. Landscape ecology and epidemiology of vector-borne diseases: tools for spatial analysis. J Med Entomol 1998; 35:435-45.

25. Thompson MC, Connor SJ. Environmental information systems for the control of arthropod vectors of disease. Med Vet Entomol 2000; 14:227-44.

26. Randolph SE. Ticks and tick-borne disease systems in space and from space. Adv Parasitol 2000; 47:217-43.

27. Bergquist NR. Vector-borne parasitic diseases: new trends in data collection and risk assessment. Acta Trop 2001; 79:13-20.

28. Huh OK, Malone JB. New tools: potential medical applications of data from new and old environmental satellites. Acta Trop 2001; 79:35-47.

29. Meneses PR, Madeira Netto JS. Sensoriamento remoto: reflectância dos alvos naturais. Brasília: Editora UNB; 2001.

30. Novo EM. Sensoriamento remoto: princípios e aplicações. São Paulo: Editora Blucher; 1989.

31. Werneck GL, Maguire JH. Modelagem espacial utilizando modelos mistos: um estudo ecológico sobre Leishmaniose Visceral em Teresina, Piauí, Brasil. Cad Saúde Pública 2002; 18:633-7.

32. Bavia ME, Malone JB, Hale L, Marroni L, Reis R. Use of thermal and vegetation index data from earth observing satellites to evaluate the risk of schistosomiasis in Bahia, Brazil. Acta Trop 2001; 79:79-85.

33. Thompson MC, Elnaiem DA, Ashford RW, Connor SJ. Towards a kala azar risk map for Sudan: map- 
ping the potential distribution of Phlebotomus orientalis using digital data of environmental variables. Trop Med Int Health 1999; 4:105-13.

34. Kitron U, Kazmierczak JJ. Spatial analysis of the distribution of Lyme disease in Wisconsin. Am J Epidemiol 1997; 145:558-66

35. Connor SJ, Thompson MC, Flasse SP, Perryman AH. Environmental information systems in Malaria: risk mapping and epidemic forecasting. Disasters 1998; 22:39-56.

36. Bittencourt MD, Mucci LF, Gomes AC, Natal D, Barata JMS, Paula MB. Imagens de satélite/SIG e risco de transmissão da malária na U.H.E. de Porto Primavera - Sp. Cadernos de Informações Georreferenciadas 1999; 1. http://www.cpa.unicamp. $\mathrm{br} / \mathrm{revista} /$ cigvln3a3.html (accessed on 09/Out/ 2003).

37. Mucci LF. Modelagem espacial do risco epidemiológico para malária em porção paulista da zona de influência do reservatório do Porto Primavera [Dissertação de Mestrado]. São Paulo: Instituto de Biociências, Universidade de São Paulo; 2000.

38. Barbieri AF, Soares BSF, Coelho LC. Uso da terra e malária: uma análise espacial para o norte do Mato Grosso, 1992 a 1995. In: Anais do XII Encontro Nacional de Estudos Populacionais; 2000 Out 23-27; Caxambu, Minas Gerais [CD-ROM].

39. Miranda C, Massa JL, Marques CA. Occurrence of American Cutaneous Leishmaniasis by remote sensing satellite imagery in an urban area of Southeastern Brazil. Rev Saúde Pública 1996; 30: 433-7.

40. Miranda C, Marques CCA, Massa JL. Satellite remote sensing as a tool for the analysis of the occurrence of American Cutaneous Leishmaniasis in Brazil. Rev Saúde Pública 1998; 32:455-63.

41. Aparício C. Utilização de geoprocessamento e sensoriamento remoto orbital para análise espacial de paisagem com incidência de leishmaniose tegumentar americana [Dissertação de Mestrado]. São Paulo: Instituto de Biociências, Universidade de São Paulo; 2001.

42. Thompson RA, Lima JWO, Maguire JH, Braud DH, School DT. Climatic and demographic determinants of American Visceral Leishmaniasis in Northeastern Brazil using remote sensing technology for environmental characterization of rain and region influences on Leishmaniasis. Am J Trop Med Hyg 2002; 67:648-55

43. Costa AIP. Estudo de fatores ambientais associados à transmissão da leishmaniose tegumentar americana através do sensoriamento remoto orbital e sistema de informação geográfica [Tese de Doutorado]. São Paulo: Faculdade de Saúde Pública, Universidade de São Paulo; 2001.

44. Lima AP. Distribuição da leishmaniose tegumentar e análise da sua ocorrência em ambientes antrópicos, no Estado do Paraná, Brasil [Dissertação de Mestrado]. Londrina: Faculdade de Medicina, Universidade Estadual de Londrina; 2000.

45. Masuoka P, Andre R, Montgomery BC, Rejmankova E, Roberts D, Carbajal F, et al. Remote sensing and GIS investigations of bartonellosis in Peru. In: IEEE International Geoscience and Remote Sensing Symposium (Igarss '98); 1998 July 6-10; Seattle, United States. Seattle: IEEE; 1998.
46. Lobitz B, Beck LR, Hug A, Wood B, Fuchs G, Faruque ASG, et al. Climate and infectious disease: use of remote sensing for detection of $\mathrm{Vib}$ rio cholerae by indirect measurement. Proc Natl Acad Sci USA 2000; 97:1438-43.

47. Aheam SC, De Rooy C. Monitoring the effects of dracunculiasis remediation on agricultural productivity using satellite data. Int J Remote Sens 1996; 17:917-29.

48. Tucker CJ, Wilson JM, Mahoney R, Anyamba A Linthicum K, Myers MF. Climatic and ecological context of the 1994-1996 Ebola outbreaks. Photogrammetric Engineering \& Remote Sensing 2002; 68:147-52.

49. Moncayo AC, Edman JD, Finn JT. Application of Geographic Information Technology in determining risk of Eastern Equine Encephalomyelitis virus transmission. J Am Mosq Control Assoc 2000; 16:28-35.

50. Malone JB, Abdel-Rahman MM, El Bahy MM, Huh OK, Shafik M, Bavia M. Geographic Information Systems and the distribution of Schistosoma mansoni in the Nile Delta. Parasitol Today 1997; 13:112-9.

51. Gong P, Spear R, Seto E, Zhou Y, Xu B, Maxzle D, et al. Remote sensing and GIS for schistosomiasis control in Sichuan, China: an overview. In: Li B, editor. Geoinformatics and socioinformatics. Proceedings of Geoinformatics'99; 1999 Jun 1921. Ann Arbor: The Association of Chinese Professionals in GIS; 1999. p. 1-9.

52. Abdel-Rahman MS, El Bahy MM, Malone JB, Thompson RA, El Bahy NM. Geographic information systems as a tool for control program management for schistosomiasis in Egypt. Acta Trop 2001; 79:49-57.

53. Malone JB, Yilma JM, McCarroll JC, Erko B, Mukarartiwa S, Zhou X. Satellite climatology and the environmental risk of Schistosoma mansoni in Ethiopia and East Africa. Acta Trop 2001; 79:5972 .

54. Kristensen TK, Malone JB, McCarrooll JC. Use of Satellite Remote Sensing and Geographic Information Systems to model the distribution and abundance of snail intermediate hosts in Africa: a preliminary model for Biomphalaria pfeifferi in Ethiopia. Acta Trop 2001; 79:73-8.

55. Brooker S, Hay SI, Issae W, Hall A, Kihamia CM, Lwambo NJS, et al. Predicting the distribution of urinary schistosomiasis in Tanzania using satellite sensor data. Trop Med Int Health 2001; 6:9981007.

56. Zhou XN, Malone JB, Kristensen TK, Bergquist NR. Application of Geographic Information Systems and Remote Sensing to schistosomiasis control in China. Acta Trop 2001; 79:97-106.

57. Brooker S, Hay SI, Tchuenté LAT, Ratard R. Using NOAA-AVHRR data to model human helminth distributions in planning disease control in Cameroon, West Africa. Photogrammetric Engineering \& Remote Sensing 2002; 68:175-9.

58. Brooker S. Schistosomes, snails and satellites. Acta Trop 2002; 82:207-14

59. Fuentes MV, Malone JB, Mas-Coma S. Validation of a mapping and prediction model for human fasciolosis transmission in Andean very high alti- 
tude endemic areas using Remote Sensing data. Acta Trop 2001; 79:87-95.

60. Anyamba A, Linthicum KJ, Mahoney R, Tucker CJ, Kelley PW. Mapping potential risk of rift valley fever outbreaks in African savannas using vegetation index time series data. Photogrammetric Engineering \& Remote Sensing 2002; 68:137-45.

61. Tran A, Gordon J, Weber S, Polidori L. Mapping disease incidence in suburban areas using remotely sensed data. Am J Epidemiol 2002; 156: 662-8.

62. Thompson DF, Malone JB, Harb M, Faris R, Huh OK, Buck AA, et al. Bancroftian filariasis distribution and diurnal temperature differences in the Southern Nile Delta. Emerg Infect Dis 1996; 2:234-5

63. Boone JD, McGwire KC, Otteson EW, Debaca RS, Kuhn EA, Villard P, et al. Remote Sensing and Geographic Information Systems: charting Sin Nombre virus infections in deer mice. Emerg Infect Dis 2000; 6:248-58.

64. Glass GE, Cheek JE, Patz JA, Shields TM, Doyle TJ, Thoroughman DA, et al. Using remotely sensed data to identify areas at risk for hantavirus pulmonary syndrome. Emerg Infect Dis 2000; 6:23847.

65. Khan AS, Young JC. Hantavirus pulmonary syndrome: at the crossroads. Curr Opin Infect Dis 2001; 14:205-9.

66. Cross ER, Newcomb WW, Tucker CJ. Use of weather data and remote sensing to predict the geographic and seasonal distribution of Phlebotomus papatasi in Southwest Asia. Am J Trop Med Hyg 1996; 54:330-2.

67. Aparício C, Dantas-Bittencourt M. Análise espacial da leishmaniose tegumentar americana. In: Anais do XI Simpósio Brasileiro de Sensoriamento Remoto; 2003 Abr 5-10; Minas Gerais, Brasil. Belo Horizonte: Instituto Brasileiro de Pesquisas Espaciais; 2003.

68. Dister SW, Fish D, Bros SM, Frank DH, Wood BL. Landscape characterization of peridomestic risk for Lyme disease using satellite imagery. Am J Trop Med Hyg 1997; 57:687-92.

69. Kitron U, Otieno LH, Hungerford LL, Odulaja A, Brigham WU, Okello OO, et al. Spatial analysis of the distribution of Tsetse flies in the Lambwe Valley, Kenya, using Landsat Tm Satellite Imagery and GIS. Journal of Animal Ecology 1996; 65:371-80.

70. Estrada-Peña A. Geostatistics and remote sensing as predictive tools of tick distribution: a cokriging system to estimate Ixodes scapularis (Acari: Ixodidae) habitat suitability in United States and Canada from advanced very high resolution radiometer satellite imagery. J Med Entomol 1998; 35:989-95.

71. Guerra M, Walker E, Jones C, Paskewitz S, Cortinas MR, Stancil A, et al. Predicting the risk of Lyme disease: habitat suitability for Ixodes scapularis in the North Central United States. Emerg Infect Dis 2002; 8:289-95.

72. Estrada-Peña A. Increasing habitat suitability in the United States for the tick that transmits Lyme disease: a remote sensing approach. Environ Health Perspect 2002; 110:635-40.

73. Roberts DR, Paris JF, Manguin S, Harbach RE, Woodroff R, Rejmankova E, et al. Predictions of malaria vector distribution in Belize based on multispectral satellite data. Am J Trop Med Hyg 1996; 54:304-8.

74. Rodriguez AD, Rodriguez MH, Hernandez JE, Dister SW, Beck LR, Rejmankova E, et al. Landscape surrounding human settlements and malaria mosquito abundance in Southern Chiapas, Mexico. J Med Entomol 1996; 33:39-48.

75. Thompson MC, Connor SJ, Milligan PJ, Flasse SP. The ecology of malaria as seen from earth-observation satellites. Ann Trop Med Parasitol 1996; 90:243-64.

76. Beck LR, Rodriguez MH, Dister SW, Rodriguez AD, Washino RK, Roberts DR. Assessment of a remote sensing based model for predicting malaria transmission risk in villages of Chiapas, Mexico. Am J Trop Med Hyg 1997; 56:99-106.

77. Thompson MC, Connor SJ, Milligan P, Flasse SP. Mapping malaria risk in Africa. What can satellite data contribute? Parasitol Today 1997; 13:313-8.

78. Hay SI, Snow RW, Rogers DJ. Predicting mosquito habitat to malaria seasons using remotely sensed data: practice, problems and perspectives. Parasitol Today 1998; 14:306-13.

79. Hay SI, Snow RW, Rogers DJ. Predicting malaria seasons in Kenya using Multitemporal Meteorological Satellite Sensor Data. Trans R Soc Trop Med Hyg 1998; 92:12-20.

80. Rejmankova E, Pope KO, Roberts DR, Lege MG, Andre R, Greico J, et al. Characterization and detection of Anopheles vestitipennis and Anopheles punctimacula (Diptera: Culicidae) larval habitats in Belize with field survey and SPOT satellite imagery. J Vector Ecol 1998; 23:74-99.

81. Thompson MC, Connor SJ, D'Alessandro U, Rowlingson B, Diggle P, Cresswell M, et al. Predicting malaria infection in Gambian children from satellite data and bed net use surveys: the importance of spatial correlation in the interpretation of results. Am J Trop Med Hyg 1999; 61:2-8.

82. Anno S, Takagi M, Tsuda Y, Yotopranoto S, Dachlan YP, Bendryman SS, et al. Analysis of relationship between Anopheles subpictus larval densities and environmental parameters using Remote Sensing (RS), Global Positioning Systems (GPS) and a Geographic Information System (GIS). Kobe J Med Sci 2000; 46:231-43.

83. Jeanne I. Malaria and schistosomiasis: 2 examples using systems of geographical information and teledetection in Madagascar. Bull Soc Pathol Exot 2000; 93:208-14.

84. Hay SI, Omumbo JA, Craig MH, Snow RW. Earth observation, geographic information systems, and Plasmodium falciparum malaria in Sub-Saharan Africa. Adv Parasitol 2000; 47:173-215.

85. Thomas CJ, Lindsay SW. Local-scale variation in malaria infection amongst rural Gambian children estimated by satellite remote sensing. Trans R Soc Trop Med Hyg 2000; 94:159-63.

86. Claborn DM, Masuoka PM, Klein TA, Hooper T, Lee A, Andre RG. A cost comparison of two malaria control methods in Kyunggi Province, Republic of Korea, using Remote Sensing and Geographic Information Systems. Am J Trop Med Hyg 2002; 66:680-5.

87. Omumbo JA, Hay SJ, Goetz SJ, Snow RW, Rogers 
DJ. Updating historical maps of malaria transmission intensity in East Africa using remote sensing. Photogrammetric Engineering \& Remote Sensing 2002; 68:161-6.

88. Rogers DJ, Randolph SE, Snow RW, Hay SI. Satellite imagery in the study and forecast of malaria. Nature 2002; 415:710-5.

89. Dale PER, Morris CD. Culex annulirostris breeding sites in urban areas: using Remote Sensing and Digital Image Analysis to develop a rapid predictor of potential breeding areas. J Am Mosq Control Assoc 1996; 12:316-20.

90. Rogers DJ, Hay SI, Packer MJ. Predicting the distribution of tsetse flies in West Africa using temporal Fourier processed meteorological satellite data. Ann Trop Med Parasitol 1996; 90:225-41.

91. Robinson TP, Rogers D, Williams B. Univariate analysis of tsetse habitat in the common fly belt of Southern Africa using climate and remotely sensed vegetation data. Med Vet Entomol 1997; 11:223-34.
92. Robinson TP, Rogers D, Williams B. Mapping Tsetse habitat suitability in the common fly belt of Southern Africa using multivariate analysis climate and remotely sensed vegetation data. Med Vet Entomol 1997; 11:235-45.

93. Hendrickx G, Nepala A, Rogers D, Bastiaensen P, Slingenbergh J. Can remotely sensed meteorological data significantly contribute to reduce costs of tsetse surveys? Mem Inst Oswaldo Cruz 1999; 94:273-6.

94. Rogers DJ. Satellites, space, time and the African trypanosomiases. Adv Parasitol 2000; 47:129-71.

95. De La Rocque S, Michael JF, De Wispelaere G, Cuisance D. New tools for the study of animal trypanosomiasis in the Sudan: model-building of dangerous epidemiological passage by Remote Sensing Geographic Information Systems. Parasite $2001 ; 8: 171-95$

Submitted on 15/Aug/2003

Final version resubmitted on $02 / \mathrm{Dec} / 2003$

Approved on 15/Dec/2003 